\title{
HIPERTERMIJOS IR DEHIDRATACIJOS POVEIKIS SUAUGUSIŲJŲ GRIAUČIŲ RAUMENŲ NUOVARGIUI ATLIEKANT MAKSIMALAUS INTENSYVUMO IZOMETRINIUS PRATIMUS
}

\author{
Kazys Vadopalas, Marius Brazaitis, Albertas Skurvydas, Nerijus Eimantas \\ Lietuvos kūno kultūros akademija, Kaunas, Lietuva
}

\begin{abstract}
Kazys Vadopalas. Biomedicinos mokslų daktaras. Lietuvos kūno kultūros akademijos Taikomosios fiziologijos ir kineziterapijos katedros lektorius. Moksliniu tyrimu kryptis — hipertermijos ir dehidratacijos poveikis raumenų nuovargiui.
\end{abstract}

\section{SANTRAUKA}

Tyrimo tikslas — nustatyti hipertermijos ir dehidratacijos poveiki nesportuojančiu vyru ir moteru griaučiu raumenu funkcijoms, ištirti rehidratacijos poveiki centriniam (CNS) nuovargiui hipertermijos salygomis atliekant didelio intensyvumo fizini krūvi. Tiriamieji - suauge aktyviai nesportuojantys vyrai $(n=10)$ ir suaugusios aktyviai nesportuojančios moterys $(n=10)$. Vyru amžius 22,2 $\pm 3,4$ m., küno svoris 75,1 $\pm 8,0 \mathrm{~kg}$, ūgis 177,6 $\pm 7,2 \mathrm{~cm}$. Moteru amžius 21,2 $\pm 2,4$ m., kūno svoris 64,84 $\pm 8,4 \mathrm{~kg}$, ügis 170,8 $\pm 2,5 \mathrm{~cm}$.

Atlikti trys tyrimai - vienas kontrolinis ir du eksperimentiniai. Eksperimentinio hipertermijos tyrimo metu buvo sukeliama organizmo hipertermija ir dehidratacija (tiriamieji 45 min sédejo panirę iki juosmens šiltoje vonioje, kurios vandens temperatūra $44 \pm 1$ C). Eksperimentinio rehidratacijos tyrimo metu ta pačia metodika sukeliant hipertermija

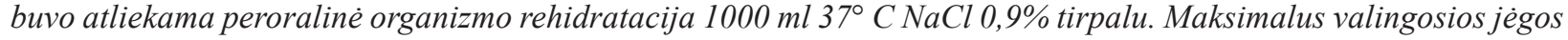
izometrinis krūvis truko $120 \mathrm{~s}$ (MVJ-2 min): kas 15 s raumuo buvo stimuliuojamas elektros impulsais - stimuliacijos trukme $250 \mathrm{~ms}$, dažnis $100 \mathrm{~Hz}$, itampos dydis 85-105 V. Registruotas raumenu maksimaliosios valingos jègos (MVJ) momentas (N•m) ir centrinés aktyvacijos santykis (CAR\%): CAR\% = MVJ / (MVJ + TT - $100 \mathrm{~Hz}) \times 100$. Sukèlus hipertermija, dehidratacija ir atlikus rehidratacija hipertermijos salygomis rektaline vyru ir moteru kūno temperatūra vidutiniškai padidejo $\sim 3^{\circ} \mathrm{C}(p<0,001)$. Eksperimentinio hipertermijos tyrimo metu vyrai vidutiniškai neteko $1,17 \pm 0,4 \%$ kūno masès $\left(I^{\circ}\right.$ dehidratacija), moterys - 0,62 $\pm 0,13 \%$. Išanalizavus fiziologini (šilumos) indeksq (FSI) nustatyta, kad vyrai patyré vidutinio ir aukšto lygio fiziologini stresq (hipertermijos atveju - 6,42 $\pm 0,71$, rehidratacijos - 7,16 $\pm 0,91$ ). Moterys patyre aukšto lygio fiziologini stresa (hipertermijos atveju $-8,85 \pm 1,13$,

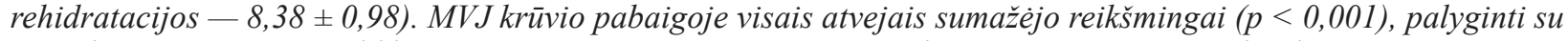
prieš krūvì nustatytais rodikliais. Atsigavimo metu, praèjus 15 s po krūvio, jëga grižo ì pradini lygi.

Dvieju veiksniu dispersine analizè atskleidè, kad analizuojamujègos rodikliu pokytis priklausè nuo laiko (p <0,001), o hipertermijos dydžio ir squeikos tarp ju rezultato reikšmingai nepaveike $(p>0,05)$. Išanalizavus raumenu valingos aktyvacijos rodiklius pastebèta, kad hipertermija $(p<0,05)$ ir rehidratacija $(p<0,01)$ reikšmingai sumažino CAR\%, palyginti su prieš krūvi nustatytu. Taikydami pasyvaus raumenu šildymo metodika, sukèleme tiriamuju organizmo hipertermija ir $I^{\circ}$ dehidratacija. Hipertermija padidino centrini nuovargi. Eksperimentiniu hipertermijos ir rehidratacijos tyrimu metu MVJ nuovargis kito vienodai. Po prieškrūvinès rehidratacijos hipertermijos salygomis vyru ir ir moteru centrinis nuovargis padidejo atliekant MVJ-2 min.

Raktažodžiai: hipertermija, izometrinis krūvis, dehidratacija, rehidratacija, centrinis nuovargis.

\section{IVADAS}

$\mathrm{L}$ iteratūroje nuolatos keliama hipotezè, kad pavojingai aukšta vidinè kūno temperatūra tiesiogiai padidina nuovargị ir pagreitina išsekimą, pastaroji tema plačiai nagrinejjama, tačiau esminiai mechanizmai nèra aiškūs (Morrison et al., 2004). Hipertermijos sąlygomis atsiranda vietiniu raumens pokyčiu, padidèja raumenų susitraukimo ir atsipalaidavimo greitis, dèl to padidèja nevalinga raumens susitraukimo jèga ir galingumas (Bružas et al., 2003). B. Nielsen ir kt. (1990) įrodè, kad karšto oro sąlygomis atliekant fizinius pratimus, kai ašinè temperatūra viršija $39^{\circ} \mathrm{C}$, sukeliamas centrinis nuovargis. Eksperimentiniu būdu pavyko nustatyti, kad hipertermijos metu atliekant fizini 
krūvị sulètėjo galvos smegenų kraujotaka (Nybo et al., 2002), elektroencefalogramoje (EEG) buvo nustatytas frontalinès motorinès galvos smegenu žievès bioelektrinių impulsų susilpnèjimas (Nielsen et al., 2001). Šis cerebrinis pokytis atsiranda anksčiau nei pradeda mažèti fizinis pajègumas (Morrison et al., 2004). Pastarieji mokslininkai pastebejo, kad atliekant izometrinius pratimus padidèjusi ašinè kūno temperatūra yra tiesiogiai susijusi su centriniu nuovargiu. M. M. Thomas ir kt. (2006) tyrimu įrode, kad hipertermija sumažina neuroraumenini darbingumą, ir tai priklauso nuo centrinès nervų sistemos negalèjimo geriau aktyvuoti raumens.

Hipertermijos metu vykstanti temperatūrinè homeostaze didina prakaitavimą ir širdies kraujagyslių sistemos darbą (Armstrong, 2000). Priežastis, dèl kurios gali sumažèti raumenų fizinis darbingumas, yra skysčiu netekimas organizme dehidratacija. Dirbant karšto klimato sąlygomis ar atliekant didelio intensyvumo ilgos trukmès fizinius pratimus, žmogus vidutiniškai netenka 0,8-1,4 1/ h prakaito (Armstrong, 2000). Didžiausias nustatytas prarandamo prakaito kiekis 3,7 1/ h (Armstrong, 1986). Aklimatizuoti žmonès kartu su prakaitu netenka apie $0,8-2,0 \mathrm{~g} \mathrm{NaCl} / 1$, o neaklimatizuoti - apie 3,0-4,0 g NaCl / 1 (Armstrong, 2000). Pastarieji elektrolitai žmogaus organizme yra laikomi pagrindiniais, kuriu dèka palaikoma vandens pusiausvyra viduląstelineje ir tarpląstelinèje terpejje, nervinis laidumas, ląstelinis metabolizmas ir kraujo tūris - osmoreguliacija ir spaudimas (Armstrong, 2000). Didžiausias skysčiu kiekis, kurị fiziškai aktyvių žmonių organizmas gali pasisavinti, yra apie 0,8-1,2 1/ h (Coyle, Hamilton, 1990). Netektų skysčiu ir $\mathrm{NaCl}$ kiekis (dèl dehidratacijos), taip pat cirkuliuojančio kraujo tūris po sporto varžybų gali būti visiškai atgaunamas duodant gerti fiziologini $0,9 \% \mathrm{NaCl}$ tirpala (Shirreffs et al., 2004).

Manoma, kad vyru ir moteru fiziologinis atsakas i fizinio krūvio sukeltą šiluminį stresą turètu taip pat skirtis (Moran et al., 1999). Moterys, lyginant su vyrais, yra mažesnio ŠKS ir kvėpavimo sistemos pajègumo, turi daugiau kūno riebalinio audinio, mažesnę kūno masę, mažesnį kūno paviršiaus plotą bei didesnị santykị tarp kūno paviršiaus ploto ir masès, ju kūne yra santykiškai mažiau vandens (Lindle et al., 1997). Be to, hormoninè estrogeno ir progesterono kaita menstruacinio ciklo metu gali paveikti moteru fizini darbingumą ir toleranciją fizinio krūvio sukeltam šiluminiam stresui (Rothchild, Barnes, 1952).
Moterys, atlikdamos mažo arba vidutinio intensyvumo ištvermès reikalaujančius izometrinius fizinius pratimus, yra ištvermingesnès nei vyrai (Fulco et al., 1999). Mechanizmas, aiškinantis ši ištvermès skirtumą laiko atžvilgiu, nèra iki galo aiškus (Hunter, Enoka, 2001). Tačiau yra dvi labiausiai paplitusios hipotezès: pirma — jègos skirtumas atsiranda dèl skirtingos raumenu masès, antra - dél skirtingos raumenu aktyvacijos (Clark et al., 2003). Vyrai turi didesnę greituju raumeninių skaidulų masę negu lètujų. Moterų šis santykis - priešingas (Staron, Hagerman, 2000). Keletas tyrimų parodè, kad moterų termoreguliacija yra mažiau veiksminga nei vyrų, kai susiduriama su dideliu šiluminiu stresu ir fizine veikla (McLellan, 1998).

Per sporto pratybas ir varžybas dažnai susiduriame su hipertermijos ir dehidratacijos reiškiniais, kurie trukdo pasiekti gerus sportinius rezultatus. Iki šiol literatūroje nepavyko rasti duomenų, irodančių, koki termini poveiki patiria vyrai ir moterys, pasyviai sukèlus organizmo hipertermiją ir dehidrataciją, ir kaip tai veikia nesportuojančiu asmenu atsparumą centriniam nuovargiui. Nėra iki galo aiškus prieškrūvinès rehidratacijos poveikis hipertermijos sąlygomis atliekant didelio intensyvumo fizini krūvị.

Tyrimo tikslas - nustatyti hipertermijos ir dehidratacijos poveikį nesportuojančių vyrų ir moterų griaučių raumenų funkcijoms, ištirti rehidratacijos poveiki centriniam (CNS) nuovargiui hipertermijos sąlygomis atliekant didelio intensyvumo fizinị krūvị.

\section{TYRIMO METODIKA}

Tiriamieji - sveiki fiziškai aktyvūs vyrai $(\mathrm{n}=10)$ ir moterys $(\mathrm{n}=10)$. Vyrų amžius 22,2 $\pm 3,4$ m., kūno masė 75,1 $\pm 8,0 \mathrm{~kg}$, ūgis $177,6 \pm 7,2 \mathrm{~cm}$. Moteru amžius 21,2 $\pm 2,4 \mathrm{~m}$., kūno masè $64,84 \pm 8,4 \mathrm{~kg}$, ūgis $170,8 \pm 2,5 \mathrm{~cm}$. Visos moterys tirtos po mènesinių iki 12 ciklo dienos, kai jų ašinè temperatūra buvo žemiausia (Horvath, Derinkwater, 1982). Tiriamieji buvo supažindinti su tyrimo tikslais, procedūra ir galimais nepatogumais. Norą dalyvauti tyrime jie patvirtino raštu. Tyrimas atliktas laikantis 1975 m. Helsinkio deklaracijoje priimtų principu dèl eksperimentų su žmonèmis etikos. Tyrimo protokolas aptartas ir patvirtintas Kauno regioniniame biomedicininių tyrimų etikos komitete (Protokolo Nr. 130 / 2005; Leidimo Nr. BE-2$54)$. 
Dinamometro nustatymas ir padėties sureguliavimas. Tiriamieji sėdejo įrenginio kèdeje, testuojamoji dešinè koja ittvirtinama blauzdos tvirtinimo įtaisu. Nustatoma kelio sąnario anatomine ašis ir sulyginama su dinamometro dianaminès apkrovos mazgo ašimi. Nustatoma visa kelio sąnario amplitude (blauzdą ištiesus $0^{\circ}$ ir sulenkus $115^{\circ}$ kampu). Norint sumažinti kūno inercini svyravima, tiriamasis buvo apjuosiamas pečių, liemens ir šlaunies diržais. Blauzda sutvirtinama diržu distaliame trečdalyje, $4 \mathrm{~cm}$ virš kulnakaulio gumburo. Koja pasveriama tada, kai ji fiksuota $72 \pm 5^{\circ} \mathrm{kampu}$ (gravitacinès sunkio jègos momentu). Valdymo skyde pasirenkamas izometrinis režimas. Fiksavus koją per kelio sąnarị $120^{\circ} \mathrm{kampu}$ (iš vidinès pusès), registruotas maksimaliosios valingos jẻgos momentas $(\mathrm{N} \cdot \mathrm{m})$ ir nevalinga (elektriniu impulsu sukelta) jèga.

Tyrimų logika. Prieš kiekvieną tyrimą buvo atliekamas žvalgomasis tyrimas, kurio metu tiriamieji turejo priprasti prie laboratorijos aplinkos sąlygu ir pasimokyti atlikti maksimalaus valingo izometrinio raumenų susitraukimo krūvị (MVJ), kiekvienam individualiai buvo parenkamas stimuliacijos itampos dydis. Ne anksčiau kaip po savaitès tiriamieji, atrinkti atsitiktiniu būdu, atliko kontrolini arba vieną iš eksperimentinių tyrimų. Prieš kiekvieną tyrimą tiriamieji, atvykę i laboratorija, 30 minučiu ramiai seddedavo iprastinès temperatūros kambaryje $\left(21,5 \pm 0,5^{\circ} \mathrm{C}\right)$, santykinè oro drègmè visų tyrimų metu $-40 \pm 0,5 \%$. Prieš kiekvieną tyrimą buvo atliekama standartine pramankšta - 10 minučių bėgimas (pulso dažnis 110 - 130 k. / min). Po pramankštos tiriamieji atsisèsdavo ị izokinetinio dinamometro kèdę ir pabūdavo ramiai 5 minutes. Kiekvieną tyrimą sudare trys - vienas kontrolinis ir du eksperimentiniai.

Pirmas eksperimentinis (hipertermijos) tyrimas nuo kontrolinio skyrèsi tuo, kad jo metu po kontrolinių MVJ matavimų tiriamiesiems buvo sukeliama hipertermija taikant modifikuotą A. J. Sargeant (1987) pasiūlytą pasyvaus kojų raumenų šildymo metodiką. Antro eksperimentinio (rehidratacijos) tyrimo metu, ta pačia metodika sukeliant hipertermiją, buvo atliekama peroralinè organizmo rehidratacija $1000 \mathrm{ml} 37^{\circ} \mathrm{C}$ (kūno temperatūros) $\mathrm{NaCl} 0,9 \%$ tirpalu.

Taikant pasyvaus kūno šildymo metodiką, tiriamieji, atvykę i laboratoriją, 30 minučių ramiai sėdèdavo iprastinès temperatūros kambaryje $\left(20-22^{\circ} \mathrm{C}\right)$. Paskui jie buvo sveriami, matuojama jų rektalinè ir paviršinè odos temperatūra. Po 10 minučiu pramankštos tiriamieji atsisèsdavo i izokinetinio dinamometro kèdę ir pabūdavo ramiai 5 minutes. Paskui buvo atliekama TT-100 Hz elektrostimuliacija (stimuliacijos trukmè $250 \mathrm{~ms}$, dažnis $100 \mathrm{~Hz}$, itampos dydis 85-105 V). Po 2 minučių buvo atliekami kontroliniai MVJ matavimai, t. y. darant 2 minučiu pertraukas atlikti trys maksimalūs valingi raumenų susitraukimai tiesiant blauzdą per kelio sąnari, fiksuotą $120^{\circ} \mathrm{kampu}$. Raumenu izometrinio susitraukimo trukmé $5 \mathrm{~s}$. Maždaug 3 susitraukimo sekundę keturgalvis šlaunies raumuo buvo stimuliuojamas TT-100 Hz impulsu. Atlikus kontrolinius MVJ matavimus, kojos buvo šildomos taikant modifikuotą A. J. Sargeant (1987) metodiką. Iš karto po šildymo matuojama odos ir rektalinè temperatūra. Išlipęs iš vonios, ne vèliau kaip po 5 minučiu, tiriamasis buvo sodinamas i specialią dinamometro kèdę ir atliko 2 minučiu trukmès maksimalaus valingo izometrinio raumenų susitraukimo krūvị (MVJ-2 min), kurio metu raumuo buvo stimuliuojamas TT-100 Hz dažniu. Praejus 15 ir 300 s po krūvio, buvo atliekami kontroliniai raumenu jẻgos matavimai. Norint sumažinti aplinkos poveiki kūno temperatūrai, fizinio krūvio metu tiriamasis vilkejjo šiltą ilgą sportinę aprangą, dèvejjo pirties kepurę. Abiejų eksperimentiniu tyrimu pabaigoje tiriamieji buvo sveriami, matuojama jų rektalinè temperatūra.

Maksimalaus valingo izometrinio krūvio metodika (MVJ-2 min). Maksimalus valingos jègos izometrinis krūvis truko 2 minutes (MVJ-2 min). MVJ-2 min metu 3, 14, 29, 44, 59, 74, 89, 104 ir 119 sekundę buvo atliekama įterptinè elektrostimuliacija -250 ms trukmès $100 \mathrm{~Hz}$ dažnio elektrinių impulsų serija (TT-100 Hz), generuojama aukštos ittampos stimuliatoriaus (modelis $M G 440$, Medicor, Budapest, Hungary). Elektrostimuliacijos metu itampos dydis sieke 85-105 V. Ittampos dydis buvo parenkamas individualiai kiekvienam tiriamajam žvalgomojo tyrimo metu. Tai buvo atliekama elektrinio impulso itampą didinant tol, kol nevalinga raumenu izometrinio susitraukimo jèga pasiekdavo $70-75 \%$ maksimaliosios valingos jëgos (stimuliacijos trukmè $1 \mathrm{~s}$, dažnis $100 \mathrm{~Hz}$ ) (Nybo, Nielsen, 2001). Kas trisdešimtą MVJ-2 min sekundę, t. y. 30, 60, 90 ir $120 \mathrm{~s}$, tiriamieji trumpam ( $\sim 3$ s) nutraukdavo darbą atpalaiduodami šlaunies raumenis, ir šios pertraukos metu buvo atliekama kontroline TT-100 Hz elektrostimuliacija. Po šio stimulo tiriamieji toliau tęsé MVJ-2 min krūvi. Registruotas maksimaliosios valingos jègos momentas $(\mathrm{N} \cdot \mathrm{m})$, ivertintas centrinès aktyvacijos santykis. CAR\% nusako raumenų aktyvacijos dydi (Enoka, 2002). CAR\% = MVJ / (MVJ + elektri- 
nis impulsas) $\times 100$. Kuo didesnis CAR\%, tuo mažesnis valingos raumenų aktyvacijos rezervas. Tiriamasis krūvio metu buvo motyvuojamas verbaliniu būdu, suteikiant jam vizualią jègos signalo kitimo informacija.

Pasyvaus kūno šildymo metodika. Tiriamieji sèdèdami 45 minutes laikè kojas panardintas iki dubens šiltoje vonioje, kurios vandens temperatūra $44 \pm 1{ }^{\circ} \mathrm{C}$, kambario temperatūra $20-22^{\circ} \mathrm{C}$. Santykinė oro drègmè visų tyrimų metu $-40 \pm$ $0,5 \%$. Tiriamieji šildymo metu negalèjo naudoti jokių dirbtinio vèsinimo irenginių. Šildymo pabaigoje testuojamo raumens temperatūra $3 \mathrm{~cm}$ gylyje padideja $\sim 2,7^{\circ} \mathrm{C}$ (Sargeant, 1987). Vandens temperatūra buvo matuojama buitiniu vandens termometru, patalpos - oro termometru.

Rektalinès temperatūros matavimo metodika. Rektalinè (ašinè) temperatūra $\left(\mathrm{T}_{\mathrm{re}}\right)$ buvo matuojama zondu, apvilktu silikonine guma su imontuotu termodavikliu (Ellab, tipas Rectal pro$b e$, Danija). Tiriamasis prieš pasyvų šildymą ir po jo įsikišdavo zondą su termodavikliu i išeinamają angą (matavimo laikas $10 \mathrm{~s}$, ikišimo gylis $12 \mathrm{~cm}$ ) (Proulx et al., 2003). Zondas su termodavikliu po naudojimo buvo nuplaunamas dezinfekuojančiais skysčiais ir sterilizuojamas autoklave.

Širdies ir kraujagyslių sistemos būsenos matavimo metodika. Prieš kiekvieną eksperimentini tyrimą ir pasyvaus šildymo metu širdies susitraukimų dažnis (ŠSD) registruotas 5 sekundžių intervalais pulso matuokliu (S-625X, Polar Electro, Kempele, Finland), arterinis kraujo spaudimas (AKS) matuotas kas 5 minutes, naudojant žastini pusiau automatini kraujospūdžio matuokli (Microlife BP A80, Switzerland).

Fiziologinio (šilumos) indekso (FSI) matavimo metodika. FSI buvo skaičiuotas pagal formulę (Moran et al., 1998):

FSI $=5\left(\mathrm{~T}_{\text {rektalinè } t}-\mathrm{T}_{\text {rektalinè } 0}\right) \times\left(39,5-\mathrm{T}_{\text {rektali- }}\right.$ nè 0$)^{-1}+\left(\breve{S S D}_{t}-\breve{S S D}_{0}\right) \times\left(180-\breve{S S D}_{0}\right)$,

čia - $\mathrm{T}_{\text {rektalinè } 0}$ ir ŠSD ${ }_{0}$ - pradiniai matavimai; $\mathrm{T}_{\text {rektaline }}$ ir ŠSD $\mathrm{t}$ - per tam tikrą laiką pasikartojantys matavimai.

FSI vertinimas: streso nèra arba labai mažas $(0-2$ balai), žemas ( $3-4$ balai), vidutinis $(5-6$ balai), aukštas ( $7-8$ balai) ir labai aukštas $(9-10$ balų).

Rehidratacija. Norint atgauti prarastą skysčių kiekị, tiriamiesiems prieš 15 minučiu iki pasyvaus kūno šildymo buvo duodama gerti fiziologinio $0,9 \%$ $\mathrm{NaCl} 37^{\circ} \mathrm{C}$ (ašinès kūno temperatūros) tirpalo. Per 60 minučių (prieš pasyvų kūno šildymą ir šildymo metu) tiriamieji lètai išgerdavo $1000 \mathrm{ml}$ skysčio (po
$100 \mathrm{ml}$ kas 6 min). Prieš kiekvieną eksperimentini tyrimą ir po jo nuogi tiriamieji (sausu kūnu) buvo sveriami elektroninèmis svarstyklemis (Tanita TBF 300, JAV). Nustatytas svorio skirtumas parode skysčiu kieki, kurio neteko tiriamasis.

Matematinė statistika. Buvo skaičiuojami rodikliu aritmetiniai vidurkiai $(\bar{x})$ ir standartiniai nuokrypiai (S). Poveikio efektas tarp skirtingu eksperimentų ir laiko matavimų buvo nustatomas naudojant dviejų veiksnių dispersinę analizę. Skirtumas statistiškai reikšmingas, kai $\mathrm{p}<0,05$.

Nuovargio indekso (NI) nustatymas. $\mathrm{NI}=$ (rezultatas prieš MVJ-2 min - rezultatas po MVJ$2 \mathrm{~min}$ ) / rezultatas prieš MVJ-2 $\min \times 100 \%$.

\section{REZULTATAI}

Sukèlus hipertermiją ir dehidrataciją, vyru rektalinè kūno temperatūra vidutiniškai padidejo nuo $37,33 \pm 0,36$ iki $39,13 \pm 0,25^{\circ} \mathrm{C}(\mathrm{p}<0,001)$, atlikus rehidrataciją hipertermijos sąlygomis nuo $37,28 \pm 0,36$ iki $39,22 \pm 0,4^{\circ} \mathrm{C}(\mathrm{p}<0,001)$. Reikšmingo skirtumo tarp vertinamų būsenų nenustatyta $(\mathrm{p}>0,05)$. Moteru rektalinè kūno temperatūra vidutiniškai padidèjo nuo $37,54 \pm 0,24$ iki $39,62 \pm 0,25^{\circ} \mathrm{C}(\mathrm{p}<0,001)$, atlikus rehidratacija hipertermijos salygomis - nuo 37,48 $\pm 0,25$ iki $39,5 \pm 0,23^{\circ} \mathrm{C}(\mathrm{p}<0,001)$. Reikšmingo skirtumo tarp vertinamų būsenų nenustatyta $(p>0,05)$. Hipertermijos eksperimento metu vyrai vidutiniškai neteko $0,93 \pm 0,32 \mathrm{~kg}$ svorio, ir tai sudare $1,17 \pm 0,4 \%$ kūno masès ( $\mathrm{I}^{\circ}$ dehidratacija). Moterys vidutiniškai neteko $0,4 \pm 0,07 \mathrm{~kg}$ svorio, ir tai sudarè $0,62 \pm 0,13 \%$ kūno masès. Atlikus peroralinę rehidrataciją hipertermijos sąlygomis, vyru kūno svoris vidutiniškai padidejo $0,13 \pm 0,33 \mathrm{~kg}$, ir tai sudare $0,17 \pm 0,43 \%$ jų kūno masès. Moteru kūno svoris vidutiniškai padidejo $0,48 \pm 0,01 \mathrm{~kg}$, ir tai sudarè $0,74 \pm 0,08 \%$ kūno masès. Pastarieji rodikliai rodo, kad tiriamieji iki MVJ-2 min pradžios atgavo netektą kūno masę. Išanalizavus FSI nustatyta, kad vyrai patyrè vidutinio ir aukšto lygio fiziologini stresa (hipertermijos tyrimo metu $-6,42 \pm 0,71$, rehidratacijos $-7,16 \pm$ 0,91 ). Moterų FSI nereikšmingai didesnis (hipertermijos atveju $-8,85 \pm 1,13$, rehidratacijos $8,38 \pm 0,98(\mathrm{p}>0,05)$.

Tirdami vyru ir moteru santykinès jègos (MVJ / kūno masè) pokyčius pastebejjome, kad visų triju tyrimų metu šis rodiklis sumažejo $(\mathrm{p}<0,001)$ jau 3 krūvio sekundę ir išliko sumažèjęs iki krūvio pabaigos (1 pav.). Vèliau (A 300) nustatėme jègos atsigavimą iki pradinès reikšmès 


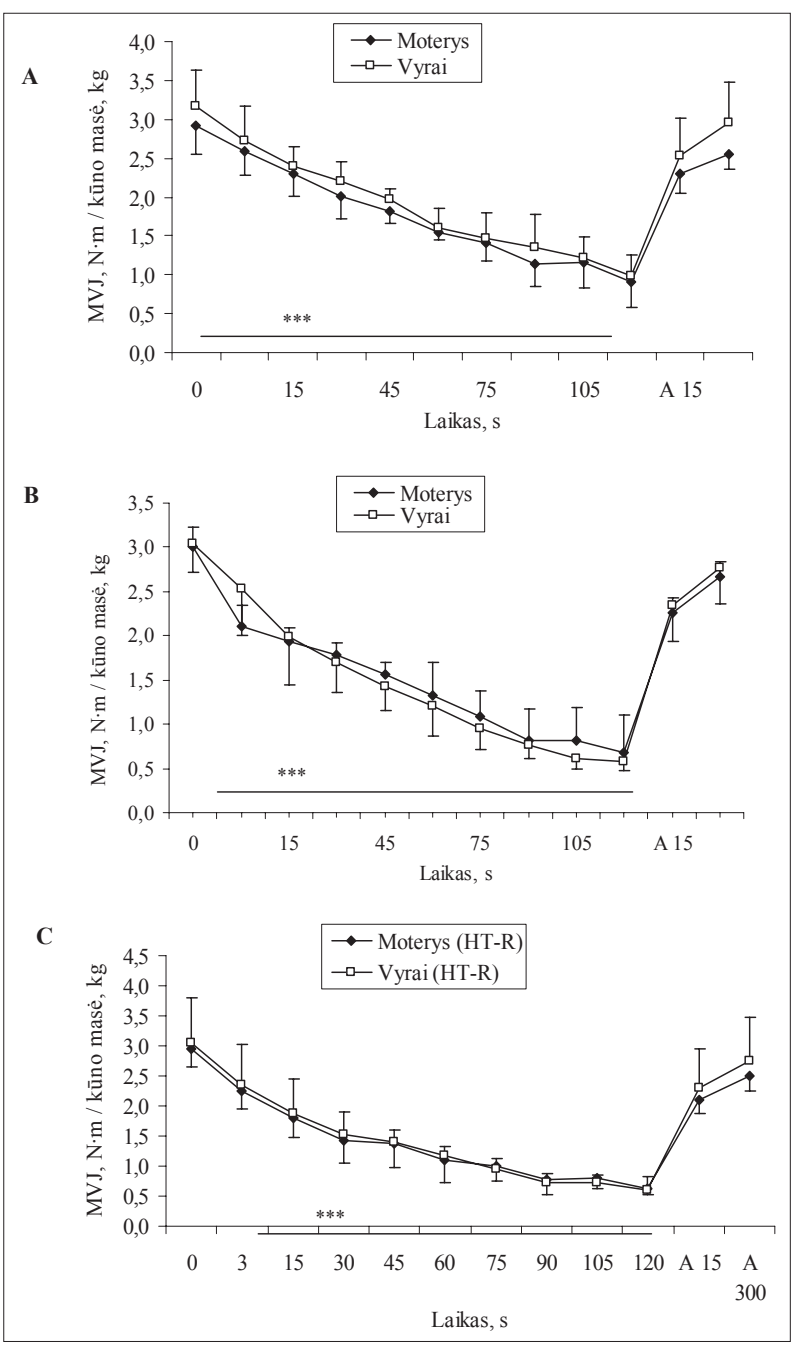

Pastaba. $* * *-$ pokytis, lyginant su pradine reikšme $(\mathrm{p}<0,001)$.

1 pav. Vyrų ir moterų maksimaliosios valingos jẻgos, tenkančios vienam kilogramui kūno masès, rodikliai (MVJ-2 min) tiesiant blauzdą per kelio sąnari fiksuotu $120^{\circ}$ kampu kontrolinio (A), hipertermijos (B) ir rehidratacijos (C) tyrimo metu

$(\mathrm{p}>0,05)$. Dviejų veiksnių dispersinè analizè atskleidè, kad analizuojamų rodikliu pokytis priklausé nuo laiko $(\mathrm{p}<0,001)$, o lytis ir sąveika tarp jų rodiklių reikšmingos įtakos neturèjo $(\mathrm{p}>0,05)$.

Atliekant MVJ-2 min, santykinès jëgos (TT$100 \mathrm{~Hz} /$ kūno masè) rodiklis sumažejo jau 60 sekundę kontrolinio ir hipertermijos tyrimo metu, o rehidratacijos metu -90 sekundę $(\mathrm{p}<0,001)$ (2 pav.). Šis statistiškai patikimas skirtumas išliko iki 15 (A 15) sekundès po krūvio. Vèliau (A 300) nustatème TT-100 Hz jègos atsigavima iki pradinès reikšmès $(p>0,05)$. Dviejų veiksnių dispersinè analizè atskleide, kad TT-100 Hz pokytis priklausè nuo laiko ir lyties, t. y. vyru nevalinga raumenu jèga buvo didesnè nei moteru $(\mathrm{p}<0,001)$.

Vyru ir moteru centrinès aktyvacijos santykio CAR\% palyginimas krūvio metu pateiktas 3 pa-

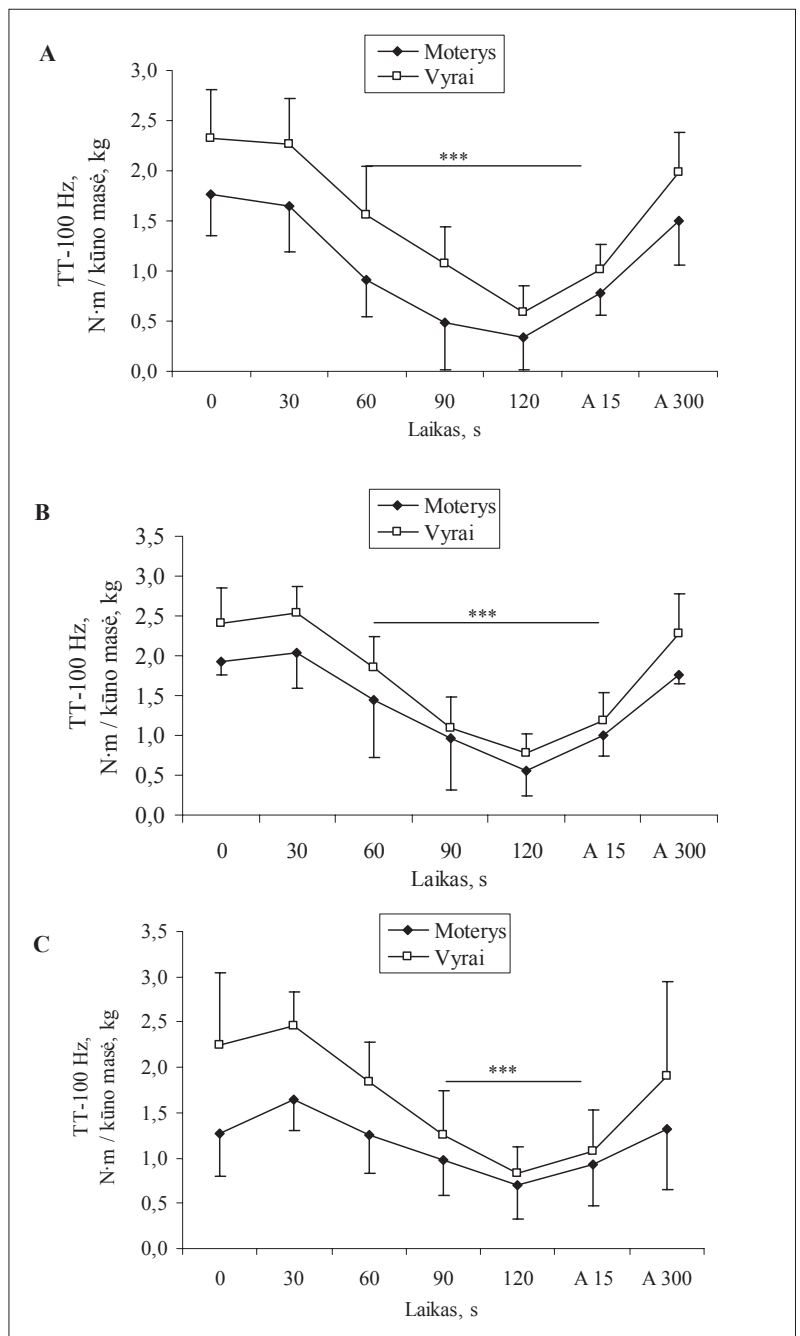

Pastaba. $* * *$ - pokytis, lyginant su pradine reikšme $(\mathrm{p}<0,001)$.

2 pav. Vyrų ir moterų nevalingos (TT-100 Hz sukeltos) jẻgos, tenkančios vienam kilogramui kūno masès, rodikliai (MVJ-2 min) tiesiant blauzdą per kelio sąnarị fiksuotu $120^{\circ}$ kampu kontrolinio (A), hipertermijos (B) ir rehidratacijos (C) tyrimo metu

veiksle. Pastebejome, kad vyrų ir moterų CAR\% visų trijų tyrimų metu 3 krūvio sekundę sumažejo reikšmingai $(\mathrm{p}<0,001)$. Šis statistiškai patikimas rodiklių sumažejimas išliko iki krūvio pabaigos. Vèliau (A 15) nustatème CAR\% grižimą i pradinị lygi $(p>0,05)$. Kontrolinio ir hipertermijos tyrimo metu nuo 3 iki 120 s pastebètas nereikšmingas CAR\% skirtumas tarp lyčių - CAR didesnis moterų negu vyrų. Tai reiškia, kad moterų centrinis nuovargis mažesnis nei vyru. Dviejų veiksnių dispersinè analizè atskleidè, kad CAR pokytis priklausè nuo laiko $(\mathrm{p}<0,05)$, o lytis ir sąveika tarp ju rodikliu reikšmingos itakos neturejo $(\mathrm{p}>0,05)$.

MVJ ir TT-100 Hz nuovargio indeksas nepriklausė nuo lyties, tyrimo sąlygų ir sąveikos tarp jų ( $p>0,05)$ (4 pav.). Tyrimo metu nustatytas nereikšmingai didesnis vyrų MVJ nuovargio indeksas. 


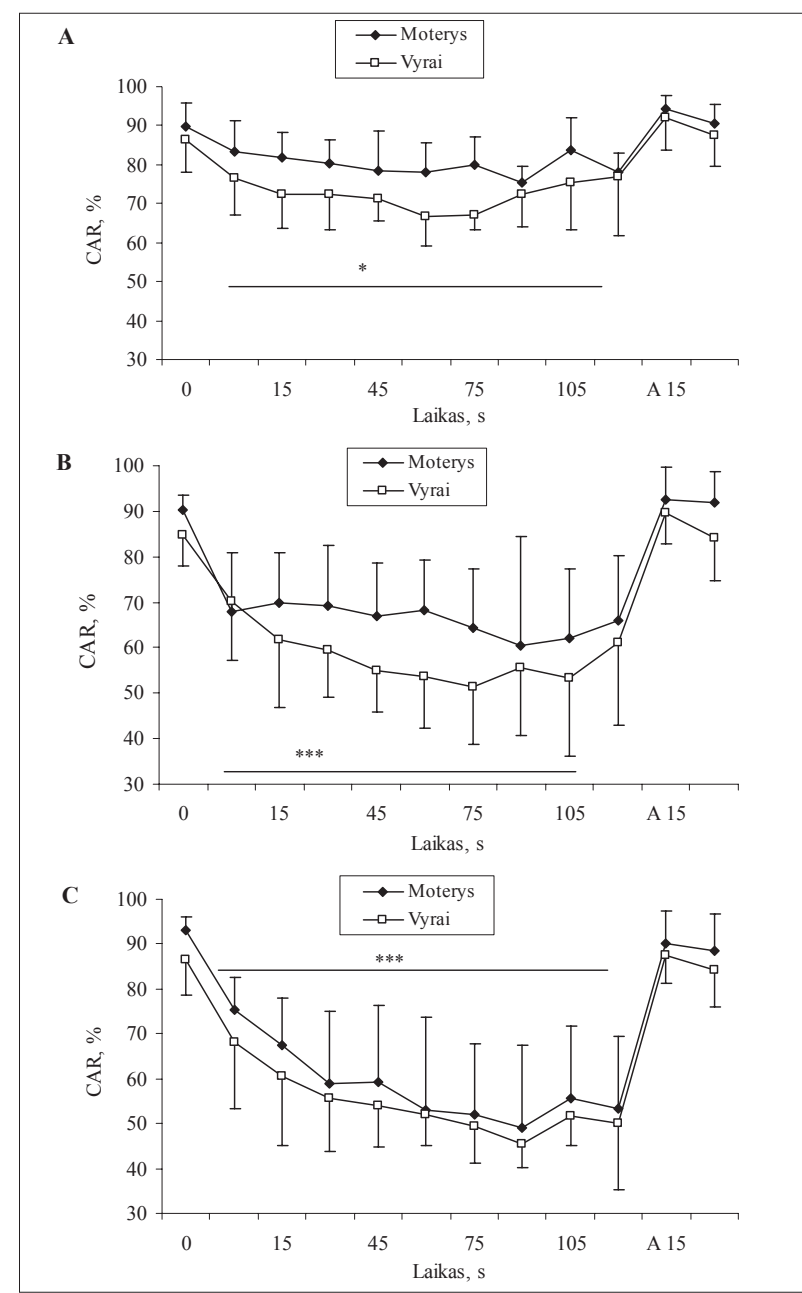

Pastaba. $* * * *$ - pokytis, lyginant su pradine reikšme $(\mathrm{p}<0,05)$, $(\mathrm{p}<0,001)$.

3 pav. Vyrų ir moterų centrinès aktyvacijos santykio (CAR\%) rodikliai (MVJ-2 min) tiesiant blauzdą per kelio sąnarị fiksuotu $120^{\circ}$ kampu kontrolinio (A), hipertermijos (B) ir rehidratacijos (C) tyrimo metu

\section{REZULTATŲ APTARIMAS}

Tyrimo tikslas buvo nustatyti, kaip fiziniu pratimų metu pasireiškianti nesportuojančių vyru ir moteru nuovargi veikia hipertermija bei dehidratacija, ar hipertermijos poveiki galima sumažinti peroraline rehidratacija. Iki šiol literatūroje nepavyko aptikti duomenų, irodančių, kokį termini poveiki patiria tiriamieji, kai jiems taikoma A. J. Sargeant (1987) pasyvaus raumenų šildymo metodika. Panašia metodika eksperimentinio hipertermijos tyrimo metu sukèlème organizmo hipertermija (rektalinè temperatūra viršijo $39^{\circ} \mathrm{C}$, padidejo šiluminio streso indeksas (FSI)) ir $\mathrm{I}^{\circ}$ dehidratacija. Aplinkos sukeltas šiluminis stresas pasireiškẻ prakaitavimo ir kardiovaskulinès sistemos atsaku, kurių paskirtis - pašalinti kūne susikaupusios šilumos perteklių (Wilmore, Costill, 2004). Tai ir yra šio tyrimo naujumas. Tyrimo metu nustatè-

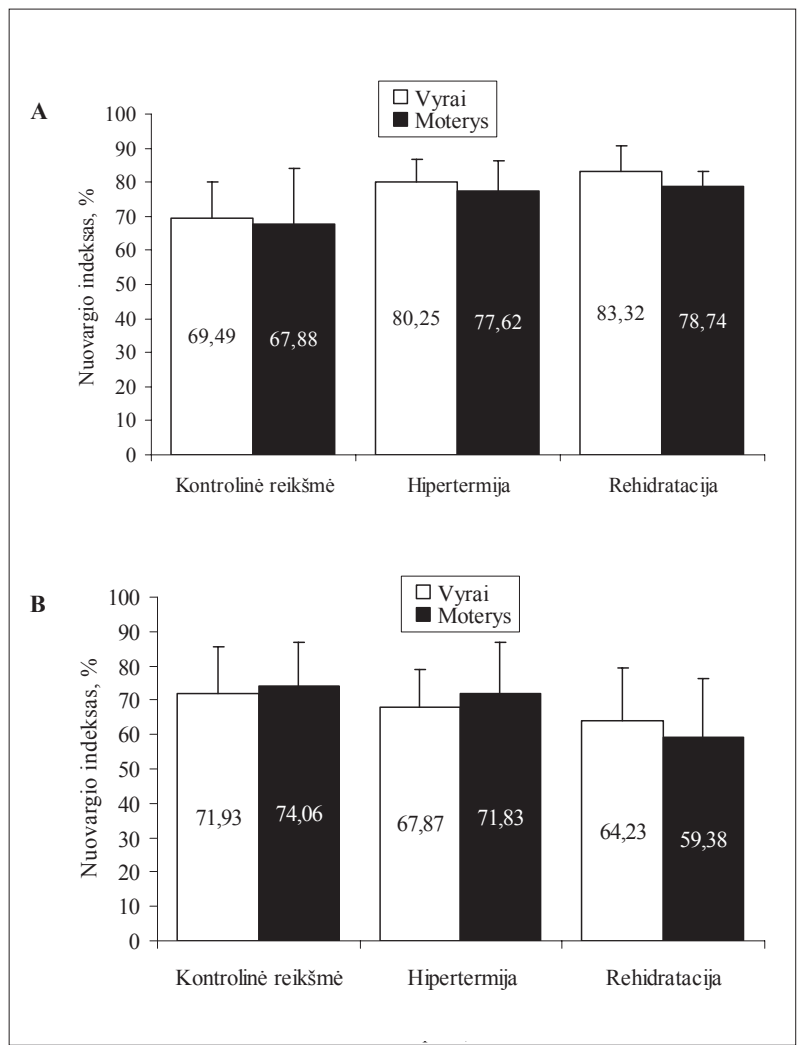

Pastaba. $p>0,05$

4 pav. Vyrų ir moterų maksimaliosios valingos (A) ir nevalingos (B) (TT-100 Hz sukeltos) jègos nuovargio indekso (skirtumas tarp kontrolinio matavimo ir 120-os krūvio sekundès) rodikliai (MVJ-2 min) tiesiant blauzdą per kelio sąnari fiksuotu $120^{\circ} \mathrm{kampu}$

me, kad vyrai neteko santykiškai daugiau skysčių ( $1-1,5 \%$ kūno masès) negu moterys $(0,4-1 \%$ kūno masès). Tiriamieji patyre vidutinio ir aukšto lygio fiziologini stresą. Nustatytas didesnis moterų FSI nei vyrų.

Šiuo metu nėra aišku, kaip pasyviai sukeltos hipertermijos neigiamas poveikis priklauso nuo dehidratacijos laipsnio. Padidejjus ašinei kūno temperatūrai iki $38,7^{\circ} \mathrm{C}$, žmogus patiria kūno perkaitimą, atsiranda nuovargis. Šio tyrimo metu nustatyta, kad hipertermija ir dehidratacija padidino maksimaliosios valingos jejgos nuovargi tiriamajam atliekant MVJ-2 min ir nustatytas mažesnis centrinès aktyvacijos santykis (CAR\%), t. y. atsirado didesnis centrinis nuovargis, lyginant su kontrolinio tyrimo duomenimis.

Rezultatai sutampa su kitų mokslininku gautaisiais, irodančiais, kad hipertermija sumažina MVJ ir valingą raumenų aktyvaciją. L. Nybo 
ir B. Nielsen (2001) ịrodè, kad 2 minučių nenutrūkstamo izometrinio fizinio krūvio pabaigoje hipertermijos metu (rektalinè temperatūra $\left.\sim 40,0^{\circ} \mathrm{C}\right) \mathrm{CAR} \%$ sumažèjo iki $54 \%$, kontrolinio tyrimo metu - $82 \%$. Mūsu atlikto hipertermijos tyrimo metu CAR\% sumažèjo iki 60\%, kontrolinio $-76 \%$. Visgi abiejų eksperimentinių tyrimu metu keturgalvis šlaunies raumuo išugde didesnę jègą, sukeltą TT-100 Hz, lyginant su kontrolinio tyrimo duomenimis. Hipertermijos sąlygomis atsiranda vietinių raumens pokyčių, padideja raumenų susitraukimo ir atsipalaidavimo greitis, dèl to padideja nevalinga raumens susitraukimo jèga ir galingumas (Bružas ir kt., 2003).

Lyginant vyrų ir moterų MVJ izometrinio krūvio metu nustatyta, kad MVJ rodikliai, tenkantys $1 \mathrm{~kg}$ kūno masès, nesiskyrè, nors vyrai išugdè didesnę absoliučią jègą. S. Welle ir kt. (2008) nustatè, kad MVJ izometrinio susitraukimo metu ir $\mathrm{VO}_{2}$ max rodikliai, tenkantys $1 \mathrm{~kg}$ kūno raumenų masès, vyrų ir moterų nesiskyrè. Taip pat buvo nustatyta didesnè vyrų nevalinga (TT-100 Hz sukelta) jèga, tenkanti vienam kilogramui kūno masès. Kai kurie autoriai teigia, kad vyrai turi didesnę raumenų masę, tenkančią $1 \mathrm{~kg}$ kūno masès, bet šie skirtumai priklauso nuo matuojamu raumenų (Fulco et al., 1999). Manoma, kad vyru ir moterų santykinė kojų raumenų masè skiriasi nedaug (Wilmore, Costill, 2004). Tiriant buvo nustatytas šiek tiek didesnis vyrų MVJ nuovargio indeksas. Vadinasi, moterys ištvermingesnès. Kai kurie autoriai mano, kad moteru raumenyse yra daugiau lètujų raumeninių skaidulų negu vyrų, raumenų susitraukimo jèga ir greitis yra mažesni, todèl moterys atsparesnès nuovargiui (Macintosh et al., 1993). Vyrų greitujų raumeniniu skaidulu masè didesnè negu lètuju. Moteru šis santykis priešingas (Staron, Hagerman, 2000).

Šio tyrimo naujumas yra tas, kad atliekant MVJ-2 min krūvi nustatytas didesnis moteru CAR\% negu vyru. Vadinasi, moteru raumenu valingos aktyvacijos lygis aukštesnis negu vyruc, ir šis vyrų ir moterų skirtumas išlieka įprastinèmis ir hipertermijos sąlygomis.

Kol kas nèra aišku, kaip prieškrūvinè rehidratacija, taikoma hipertermijos sąlygomis, veikia MVJ ir centrini nuovargi, kuris dažnai pastebimas atliekant maksimalaus intensyvumo izometrinius pratimus. Tiriant nesportuojančius vyrus ir mo- teris nustatyta, kad rehidratacija hipertermijos sąlygomis padidino centrini nuovargi atliekant MVJ-2 min. Didesni centrini nuovargi rehidratacijos tyrimo metu galëjo sukelti skysčių stazé žarnyne ir skrandyje (Noakes, 1993). Tai buvo mūsų nustatyta klinikiniais tyrimais (perkusijos ir auskultacijos metu girdejome skysčiu fliuktuaciją skrandžio plote, tiriamieji prieš fizini krūvi jautè pilnumą skrandyje ir nedideli pykinimą). Dèl vyraujančio simpatinès nervų sistemos tonuso hipertermijos sąlygomis galèjo spazmuoti skrandžio prievarčio raukas, sulètèti žarnyno motorika, susilpnèti fiziologinio tirpalo rezorbcija žarnyne. Tai ir galèjo sukelti skysčių stazę skrandyje. Itemptas nuo skysčiu skrandis suaktyvina žarnyno kraujotaką, dèl to žarnyno veninejje sistemoje galèjo padidèti cirkuliuojančio kraujo kiekis. Kraujui persiskirsčius organizme, sumažèja jo tūris, pratekantis odos kraujagyslèmis, sumažeja prakaito išskyrimas, sulètėja galvos smegenu kraujotaka (Nybo et al., 2002), dèl to dar labiau padideja centrinis nuovargis (Cheung, Sleivert 2004). Mūsų tyrimo rezultatai sutampa su kitų mokslininkų gautaisiais — dažnai pastebima, kad skysčiai ne visada yra pasisavinami žarnyne itemptas skrandis dar labiau pasunkina fizinę veiklą (Coyle, 2004).

\section{IŠVADOS}

Taikant modifikuotą pasyvaus kojų raumenu šildymo metodiką, tiriamieji patyrè organizmo hipertermiją ir dehidratacija.

Intensyvaus izometrinio krūvio metu hipertermija ir dehidratacija padidina aktyviai nesportuojančių vyrų ir moterų centrinị (CNS) nuovargi.

Iprastinèmis ir hipertermijos sąlygomis nesportuojančių moterų centrinis nuovargis mažesnis negu nesportuojančių vyrų.

Po prieškrūvinès rehidratacijos hipertermijos sąlygomis aktyviai nesportuojančiu vyru ir moteru centrinis nuovargis padidejo atliekant MVJ-2 min. 


\section{LITERATŪRA}

Armstrong, L. E., Hubbard, R. W., Jones, B. H., Daniels, J. T. (1986). Preparing Alberto Salazar for the heat of the 1984 Olympic marathon. The Physician and Sport Medicine, 14, 73-81.

Armstrong, L. E. (2000). Performing in extreme environments: The importance of dietary sodium. Human Kinetics, 38-45.

Bružas, V., Skurvydas, A., Lukošiūtè, I. (2003). Šildymo poveikis raumens nuovargiui ir atsigavimui. Ugdymas. Küno kultūra. Sportas, 2 (52), 19-24.

Cheung, S. S., Sleivert, G. G. (2004). Multiple triggers for hyperthermia fatigue and exhaustion. Journal of Exercise and Sport Sciences Reviews, 100-106.

Clark, B. C., Manini, T. M., The, D. J., Doldo, N. A., Ploutz-Snyder, L. L. (2003). Gender differences in skeletal muscle fatigability are related to contraction type and EMG spectral compression. Journal of Applied Physiology, 94, 2263-2272.

Coyle, E. F. (2004). Fluid and fuel intake during exercise. Journal of Sports Sciences, 22, 39-55.

Coyle, E. F., Hamilton, M. A. (1990). Fluid replacement during exercise: Effects on physiological homeostasis and performance. In C. V. Gisolfi, D. R. Lamb (Eds.), Fluid Homeostasis During Exercise. Perspectives in Exercise Science and Sports Medicine, 3, 281-308. Carmel, IN: Benchmark Press.

Fulco, C., Rock, P., Muza, S. et al. (1999). Slower fatigue and faster recovery of the adductor pollicis in women matched for strength with men. Acta Physiologica Scandinavica, 167, 233-239.

Horvath, S. M., Drinkwater, B. L. (1982). Thermoregulation and the menstrual cycle. Aviation, Space and Environmental Medicine, 53 (8), 790-794.

Hunter, S. K., Enoka, R. M. (2001). Sex differences in the fatigability of arm muscles depends on absoliute force during isometric contractions. Journal of Applied Physiology, 91, 2686-2694.

Lindle, R. S., Metter, E. J., Lynch, N. A. et al. (1997). Age and gender comparisons of muscle strength in 654 women and men aged 20-93 years. Journal of Applied Physiology, 83, 1581-1587.

Macintosh, B. R., Herzog, W., Suter, E., Wiley, J. P., Sokolovsky, J. (1993). Human skeletal muscle fiber types and force: Velocity properties. European Journal of Applied Physiology and Occupational Physiology, 67, 499-506.

McLellan, T. M. (1998). Sex-related differences in thermoregulatory responses while wearing protective clothing. European Journal of Applied Physiology, 78, 28-37.

Moran, D. S., Shapiro, Y., Laor, A., Izraeli, S., Pandolf, K. B. (1999). Can gender differences during exerciseheat stress be assessed by the physiological strain index? American Journal of Physiology, 45, R 1798-1804.

Moran, D. S., Shitzer, A., Pandolf, K. B., (1998). A physiological strain index to evaluate heat stress. Ambient Journal of Physiology, 275, R 129-134.

Morrison, S. A., Sleivert, G. G., Cheung, S. S. (2004). Passive hyperthermia reduces voluntary activation and isometric force production. European Journal of Applied Physiology, 91, 729-736.
Nielsen, B., Hylding, T., Bidstrup, F., Gonzalez-Alonso, J., Christoffersen, G. R. (2001). Brain activity and fatigue during prolonged exercise in the heat. Pflugers Archiv, 442 (1), 41- 48

Nielsen, B., Savard, G., Richer, E. A., Hargreaves, M., Saltin, B. (1990). Muscle blood flow and muscle metabolism during exercise and heat stress. Journal of Applied Physiology, 69 (3), 1040-1046.

Noakes, T. D. (1993). Fluid replacement during exercise. Exercise and Sport Sciences Reviews, 21, 297-330

Nybo, L., Moller, K., Voliantitis, S., Nielsen, B., Secher, S. (2002). Effects of hyperthermia on cerebral blood flow and metabolism during prolonged exercise in humans. Journal of Applied Physiology, 93, 58-64.

Nybo, L., Nielsen, B. (2001). Hyperthermia and central fatigue during prolonged exercise in human. Journal of Applied Physiology, 91, 1055-1060.

Proulx, C. I., Ducharme, M. B., Kenny, G. P. (2003). Effect of water temperature on cooling efficiency during Hyperthermia in humans. Journal of Applied Physiology, 94, 1317-1323

Rothchild, I., Barnes, A. C. (1952). Effects of dosage, and of estrogen, androgen or salicylate administration on degree of body temperature elevation induced by progesteron. Endocrinology, 50, 485-496.

De Ruiter, C. J., De Haan, A. (2000). Temperature effect on the force / velocity relationship of the fresh and fatigued human adductor pollicis muscle. European Journal of Physiology, 440, 163-170.

Sargeant, A. J. (1987). Effect of muscle on leg extension force and short-term power output in humans. European Journal of Applied Physiology, 56, 693-698.

Shirreffs, S., Armstrong, L. E., Cheuvront, S. N. (2004). Fluid and electrolyte needs for preparation and recovery from training and competition. Journal of Sports Sciences, $22(1), 57-63$.

Staron, R. S., Hagerman, F. C. (2000). Fiber Type Composition of the Vastus Lateralis Muscle of Young Men and Women. Journal of Histochemistry \& Cytochemistry, 48, $623-629$.

Thomas, M. M., Cheung, S. S., Elder, G. C., Sleivert, G. G. (2006). Voluntary muscle activation is impaired by core temperature rather than local muscle temperature. Journal of Applied Physiology, 100, 1361-1369.

Welle, S., Tawil, R., Thornton, C. A. (2008). Sex-related differences in gene expression in human skeletal muscle. Online Journal of the Public Library of Science, 3 (1), 1385.

Wilmore, J. H., Costill, D. L. (2004). Physiology of Sport and Exercise. Human Kinetics. P. 307-330. 


\title{
IMPACT OF HYPERTHERMIA AND DEHYDRATION ON THE SKELETAL MUSCLE FATIGUE OF MEN AND WOMEN PERFORMING ISOMETRIC EXERCISES OF MAXIMUM INTENSITY
}

\author{
Kazys Vadopalas, Marius Brazaitis, Albertas Skurvydas, Nerijus Eimantas \\ Lithuanian Academy of Physical Education, Kaunas, Lithuania
}

\begin{abstract}
The aim of the study was to establish the impact of hyperthermia and dehydration to not actively engaged in sports male and female adults on the functions of skeletal muscles, evaluate the impact of rehydration to central (CNS) fatigue under the conditions of hyperthermia during the maximum intensity isometric load. The research participants were male $(n=10)$ and female $(n=10)$ adults not actively engaged in sports. The male were $22.4 \pm 3.4$ years old, with body mass of $75.1 \pm 8.0 \mathrm{~kg}$, and height $-177.6 \pm 7.2 \mathrm{~cm}$, and the females were $21.2 \pm 2.4$ years old, with body mass of $64.84 \pm 8.4 \mathrm{~kg}$, and height $-170.8 \pm 2.5 \mathrm{~cm}$.

Three studies were carried out - one control study and the other two - experimental. During the hyperthermia experiment the bodies of the research participants experienced hyperthermia and dehydration (research participants kept their legs up to the pelvis in the bath with hot water $\left(44 \pm 1^{\circ} \mathrm{C}\right)$ for 45 minutes). During the rehydration experiment, using the same methods of increasing hyperthermia, the organisms experienced peroral rehydration with the $1000 \mathrm{ml}$ solution of $37^{\circ} \mathrm{C} \mathrm{NaCl} 0.9 \%$. The load of maximum voluntary strength lasted for 120 seconds (MVC-2 min), every 15 seconds the muscle was stimulated by electrical impulses - the duration of the stimulation was $250 \mathrm{~ms}$, the frequency was $100 \mathrm{~Hz}$, and the voltage was $85-105 \mathrm{~V}$. We registered the moment of maximal voluntary contraction force (MVC) $(\mathrm{N} \cdot \mathrm{m})$ and the central activation ratio $(\mathrm{CAR} \%)$. CAR $\%=\mathrm{MVC} /(\mathrm{MVC}+\mathrm{TT}-100 \mathrm{~Hz}) \times 100$. After hyperthermia, dehydration and hyperthermia were applied, the rectal male and female body temperature averagely increased by $\sim 3^{\circ} \mathrm{C}(\mathrm{p}<0.001)$. During the hyperthermia experiment the male research participants lost $1.17 \pm 0.4 \%$ of their body mass $\left(\mathrm{I}^{\circ}\right.$ dehydration) and the females lost $0.62 \pm 0.13 \%$ of their body mass. Having analyzed the physiological index of heat stress (in the 10 point system) we established that the research male participants experienced average and high level physiological stress - in the case of hyperthermia it was $6.42 \pm 0.71$, and in the case of rehydration $-7.16 \pm 0.91$, and female participants experienced high level physiological stress - in the case of hyperthermia it was $8.85 \pm 1.13$, and in the case of rehydration $-8,38 \pm 0,98$. At the end of the load the MVC decreased significantly in all the cases $(p<0.001)$, compared to the indices which were established before the load. After 15 seconds during the recovery time the strength regained the level witch was established before the load was applied. Two-factor dispersion analysis revealed that the changes in the analyzed strength indices depended on time $(\mathrm{p}<0.001)$; however, the level of hyperthermia and their interaction did not impact the results $(\mathrm{p}>0.05)$. After the analysis of the indices of muscle voluntary activation we noticed that hyperthermia $(\mathrm{p}<0.05)$ and rehydration $(\mathrm{p}<0.01)$ significantly decreased CAR\% compared to the one established before the load.

Applying the methods of passive heating of muscles the research participants were made to experience hyperthermia and $\mathrm{I}^{\circ}$ dehydration. Hyperthermia increased the central fatigue. During the experiments of hyperthermia and dehydration MVC fatigue altered at the same level. After performing rehydration under the conditions of hyperthermia before the load central fatigue of men and women not engaged in sports increased.
\end{abstract}

Keywords: hyperthermia, isometric load, dehydration, rehydration, central fatigue.

Gauta 2009 m. gruodžio 29 d.

Received on December 29, 2009

Priimta $2010 \mathrm{~m}$. balandžio $1 \mathrm{~d}$.

Accepted on April 1, 2010
Kazys Vadopalas

Lietuvos kūno kultūros akademija

(Lithuanian Academy of Physical Education)

Sporto g. 6, LT-44221 Kaunas

Lietuva (Lithuania)

Tel +370 37302671

E-mail kazysvado@yahoo.com 